\title{
Leucodystrophy and oculocutaneous albinism in a child with an 11q14 deletion
}

\author{
Isabelle Coupry, Laurence Taine, Cyril Goizet, Carine Soriano, Bruno Mortemousque, \\ Benoît Arveiler, Didier Lacombe
}

Laboratoire de

Pathologie Moléculaire et Thérapie Génique, Université Victor

Segalen Bordeaux 2, 146 Rue Léo Saignat, 33076 Bordeaux Cedex, France

I Coupry

L Taine

C Goizet

C Soriano

B Arveiler

D Lacombe

Service de Génétique

Médicale, CHU

Bordeaux, France

L Taine

C Goizet

B Arveiler

D Lacombe

Service

d'Ophtalmologie, CHU Bordeaux,

France

B Mortemousque

Correspondence to:

Dr Coupry,

Isabelle.coupry@

pmtg.u-bordeaux2.fr

Revised version received 20 July 2000

Accepted for publication

15 August 2000

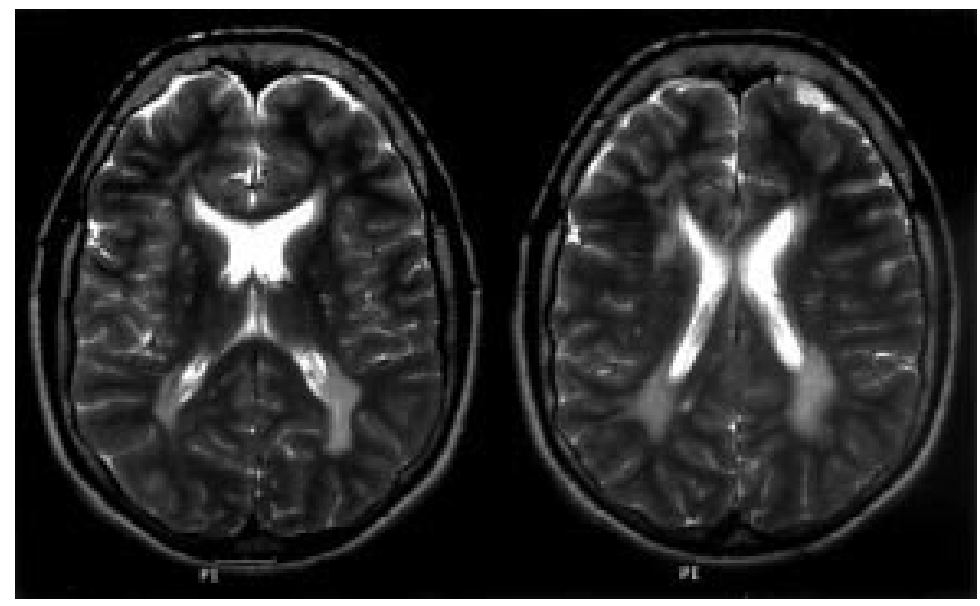

Figure 1 Cranial MRI images of the patient. Note the almost symmetrical hyperintense T2 changes throughout the periventricular regions, predominantly around the posterior horns of the lateral ventricles.

\begin{abstract}
We report a patient with an undetermined leucodystrophy associated with type 1A oculocutaneous albinism (OCA). Type 1 OCA results from recessive mutations in the tyrosinase gene (TYR) located in 11q14.3. The patient was found by FISH to carry a deletion of at least the first exon of the TYR gene on one chromosome and a (TG) deletion at codon $244 / 245$ on the second chromosome. The existence of the microdeletion suggested that a gene responsible for leucodystrophy was located in the vicinity of the $T Y R$ gene. A combination of a test of hemizygosity and contig mapping studies allowed us to map the gene within a $0.6 \mathrm{cM}$ region flanked by microsatellite markers D11S1780 and D11S931. (F Med Genet 2001;38:35-39)
\end{abstract}

Keywords: leucodystrophy; oculocutaneous albinism; 11 q14 deletion; physical mapping

The leucodystrophies are a heterogeneous group of rare hereditary diseases affecting the central nervous system (CNS). They display a heredodegenerative process mostly affecting the white matter and leading to diffuse demyelination of the CNS. Clinical evidence of the diagnosis may be confirmed by brain imaging (magnetic resonance imaging rather than CT scanning), which shows characteristic signal abnormalities in the white matter. The cause of $36 \%$ of all leucodystrophies is unknown since no specific biochemical or genetic abnormality can be identified, thus rendering the classification of patients into homogeneous subgroups impossible. ${ }^{1}$ The diagnosis is therefore made by eliminating all known abnormalities identified so far, such as raised blood levels of very long chain fatty acids in adrenoleucodystrophy, lysosomal enzyme deficiency in urine and blood in Krabbe's disease, metachromatic leucodystrophy, and Canavan's disease, or proteolipoprotein mutation in Pelizaeus-Merzbacher disease. ${ }^{2}$ A useful approach towards identifying the genes involved in these disorders is to search for chromosomal rearrangements in patients. We report a patient with an undetermined leucodystrophy associated with type 1A oculocutaneous albinism (OCA). Type 1A OCA results from deficient catalytic activity of tyrosinase, the gene for which (TYR) is located in 11q14.3. ${ }^{3}$ This gene was found by FISH to be deleted in the patient. The existence of the microdeletion suggested that the gene responsible for leucodystrophy in this patient was located in the vicinity of the TYR gene. The work presented here allowed us to map the gene within a $0.6 \mathrm{cM}$ region framed by microsatellite markers D11S1780 and D11S931.

\section{Case report}

The patient is the third and last son of non-consanguineous French parents. The family history is uninformative. The patient was born at 38 weeks' of gestation after an uneventful pregnancy and delivery (birth weight $3040 \mathrm{~g}$ ). OCA was noted at birth since there was total depigmentation of the skin, hair, and iris associated with nystagmus. The patient walked at 19 months. Speech was retarded. A visual deficit was noted in early childhood, so he was cared for in an institution for the visually deficient. Mental retardation became manifest later in childhood. At the age of 15 years, generalised epileptic episodes occurred, requiring antiepileptic treatment. An electroencephalogram was abnormal and cranial magnetic resonance imaging (MRI) showed diffuse signals of increased intensity in the white matter on T2 images typical of leucodystrophy (fig 1). At the age of 18, mental retardation was moderate $(\mathrm{IQ}=51)$. Examination showed diffuse hyperreflexia, slight dysmorphism including bulbous nose and prognathism, and gynaecomastia in addition to 


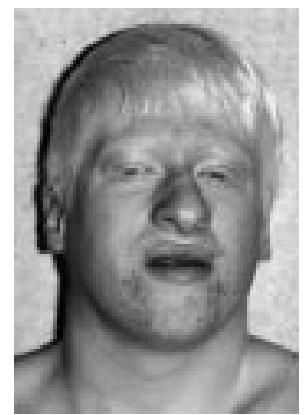

Figure 2 Patient's front view. Note the total depigmentation of the hair, eyebrows, and eyelashes as well as the slight dysmorphism with bulbous nose and prognathism. the above mentioned signs (fig 2). There was no sign of peripheral demyelination on electromyography, which displayed normal signals. P100 wave was absent on the left and very altered on the right on visual evoked potentials while somatosensory and auditory evoked potentials were normal. No abnormalities were found in standard laboratory investigations, blood amino acids on chromatography, VLCFA, phytanic acid, pipecolic acid, pristanic acid, or leucocytic lysosomal enzymes, classifying the leucodystrophy as undetermined. OCA was classified as type 1 after a search for tyrosinase activity in hair roots proved negative.

\section{Material and methods}

Informed consent was obtained from the patient before inclusion in the study.

KARYOTYPING AND FLUORESCENCE IN SITU HYBRIDISATION

Chromosome preparations were made from peripheral blood cultures by conventional methods from the patient and his parents. High resolution $\mathrm{R}$ banding was obtained by introduction of 5-bromodeoxyuridine (BrdU) for 5.5 hours in cell cultures, after thymidine synchronisation. ${ }^{4}$

A human tyrosinase recombinant $\lambda$ phage, $\lambda$ hTyr $34,{ }^{5}$ containing the first $T Y R$ exon was labelled with digoxigenin-11-dUTP using the Dig-Nick-translation kit from Boehringer Mannheim Inc. One hundred ng of the labelled DNA was preannealed with $2.5 \mu \mathrm{g} \operatorname{Cot} \mathrm{I}$ DNA (Gibco BRL) in a total volume of $10 \mu \mathrm{l}$ hybridisation $\operatorname{mix}(50 \%$ formamide, $2 \times \mathrm{SSC}$, $10 \%$ dextran sulphate) containing $0.5 \mu \mathrm{l}$ chromosome 11 alpha satellite biotinylated probe (Oncor Appligene) for 30 minutes at $37^{\circ} \mathrm{C}$. Hybridisation to denatured chromosomes was done overnight at $37^{\circ} \mathrm{C}$. Post hybridisation wash was carried out at $72^{\circ} \mathrm{C}$ in $2 \times$ SSC for five minutes. Probe detection was performed with a FITC conjugated mouse antidigoxin antibody (Sigma) and cyanin 3 conjugated extravidin (Cy3, Sigma). Using the fluorescence plus Giemsa modified method ${ }^{6}$ resulted in a high resolution $\mathrm{R}$ banding pattern. After UV exposure, a second round of signal amplification was performed with additional layers of a rabbit antimouse FITC conjugated antibody (Sigma) to amplify the TYR signal and a biotinylated goat antiavidin antibody (Vector Laboratories), shown by cyanin 3 conjugated extravidin, to amplify the chromosome 11 alpha satellite signal. Slides were mounted in antifade solution (Vectashield, Vector Laboratories) containing 4',6-diamidino-2-phenyl lindole (DAPI) as a counterstain. Slides were analysed on a Zeiss Axioskop microscope equipped with a Pinkel filter set for visualisation of FITC, Cy3, and DAPI fluorescence. Digital images were recorded with a Photometrics cooled CCD camera. Pseudocolouring and merging of images were performed with the Mac Probe 3.3 software (PSI, League City, Texas).

PCR AMPLIFICATION AND SEQUENCING OF THE TYROSINASE GENE

Primers P1 to P12 (Oligo Express, France), used to amplify the tyrosinase exons, have been previously described. ${ }^{35}$ The PCR procedures involved a first step of 10 minutes at $95^{\circ} \mathrm{C}$ to activate the AmpliTaq Gold DNA polymerase (Perkin Elmer), which was followed by 35 cycles of heat denaturation for 30 seconds at $94^{\circ} \mathrm{C}$, annealing for 30 seconds at various temperatures (exon $1,50^{\circ} \mathrm{C}, 1 \mathrm{mmol} / 1 \mathrm{MgCl}_{2}$; exons $2,3,4,50^{\circ} \mathrm{C}, 1.5 \mathrm{mmol} / 1 \mathrm{MgCl}_{2}$; and exon $5,55^{\circ} \mathrm{C}, 2.5 \mathrm{mmol} / 1 \mathrm{MgCl}_{2}$ ), and extension at $72^{\circ} \mathrm{C}$ for one minute. The reaction ended with a five minute extension step at $72^{\circ} \mathrm{C}$. The reaction buffer contained $1 \mathrm{mmol} / \mathrm{l}$ of each oligonucleotides, $0.2 \mathrm{mmol} / 1 \mathrm{dNTPs}$, and $1 \mathrm{U}$ of AmpliTaq Gold, in a $25 \mu \mathrm{l}$ reaction. Amplification was carried out using an Omnigene Thermal Cycler (Hybaid).

PCR products were purified with the QIAquick PCR purification kit (QIAGEN) according to the manufacturer's instructions and were sequenced using the dRhodamine Terminator Cycle Sequencing Ready Reaction kit (Perkin-Elmer), on an ABI377 automatic sequencer (Applied Biosystems). The DNA sequencing reactions were performed with the primers used for amplification, except for exon 1 for which two additional internal primers (1PA and $1 \mathrm{~PB}$ ) were used. ${ }^{3}$

\section{TEST FOR HEMIZYGOSITY}

The test for hemizygosity was performed with eight polymorphic microsatellite markers mapped in the vicinity of the TYR locus, according to the Marshfield Map (http:// www.marshmed.org/genetics/). Genomic DNA from the patient and his parents was amplified with 6-FAM labelled primers corresponding to microsatellites D11S931, D11S1342, D11S1354, D11S1358, D11S1367, D11S1780, D11S1887, and D11S4082. PCR parameters and cycling conditions were optimised for each marker and are available from the authors on request. Fragment length analysis was performed on an ABI377 automatic sequencer (Applied Biosystems) using the GeneScan software.

\section{Results and discussion}

KARYOTYPING AND FLUORESCENCE IN SITU HYBRIDISATION

High resolution prometaphase karyotypes were normal for the patient and his parents. High resolution prometaphase chromosomes were hybridised with both a chromosome 11 alpha satellite probe and the $\lambda \mathrm{hTyr} 34$ probe that contains the 5 ' region of the TYR gene, including exon $1 .^{5}$ The results obtained showed that TYR maps to band $11 \mathrm{q} 14.3$ (data not shown), thus refining previous mapping data reported by others in lower resolution FISH experiments ${ }^{78}$ and confirming our contig mapping data. ${ }^{3}$ FISH analysis of the patient's chromosomes showed the existence of a de novo microdeletion in 11 q14.3 (fig 3). The patient's parents did not carry the microdeletion (data not shown).

IDENTIFICATION OF THE SECOND TYR MUTATION RESPONSIBLE FOR OCULOCUTANEOUS ALBINISM Since OCA1A is an autosomal recessive trait, the second causative mutation was searched for by direct sequencing of the five TYR exons. A 


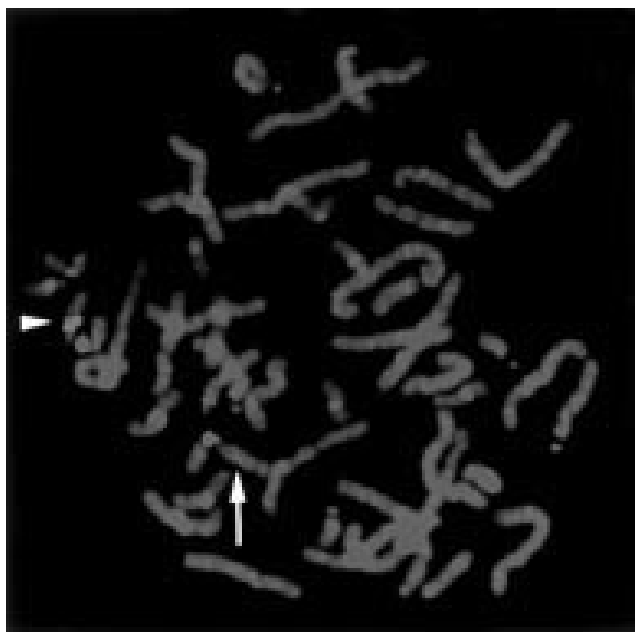

Figure 3 FISH analysis of the patient's peripheral blood lymphocytes. The digoxigenylated phage $\lambda$ hTyr34 and the biotinylated chromosome 11 alpha satellite probes were detected with a FITC conjugated antidigoxin antibody and Cy3 conjugated extravidin, respectively. Metaphase showing only the chromosome 11 alpha satellite signal (arrow) and both $\lambda$ hTyr34 and chromosome 11 alpha satellite signals on the normal chromosome 11 (arrowhead).

two base pair (TG) deletion in codons $244 / 5$ of the first TYR exon was found (fig 4), which produces a shift in the reading frame leading to a stop codon. This mutation was already described in a patient with OCA1A. ${ }^{9}$ The mutation was inherited from the father, implying that the $11 \mathrm{q} 14.3-\mathrm{q} 21$ deletion had therefore occurred on the maternal chromosome.
REFINED MAPPING OF THE DELETION BREAKPOINT REGION

In order to evaluate the extent of the deletion, a test for hemizygosity was performed using eight microsatellite markers located in the $11 \mathrm{q} 14.3$ region. The order of the markers on the Marshfield integrated map was: cen D11S1354 - D11S4082 - D11S1887 D11S1780 - D11S931 - D11S1367 D11S1342 - D11S1358 - tel. Owing to uncertainties about marker order in other databases, a PCR based STS analysis of these markers was performed on a previously constructed YAC contig encompassing about $2 \mathrm{Mb}$ of the region of interest, on which TYR, D11S931, D11S1342, and D11S1358 were already mapped. ${ }^{3}$ Data presented in fig 5 indicate that D11S1367 maps immediately proximal to $T Y R$, probably within $100 \mathrm{~kb}$ of the $5^{\prime}$ end of the gene as estimated on the basis of the YAC insert sizes. This result is at variance with the Marshfield map order. The absence of markers D11S1354, D11S4082, D11S1887, and D11S1780 on the YACs indicates that these markers are centromeric to D11S1367 and are distant from this marker by at least $300 \mathrm{~kb}$. Altogether, our data suggest that the order of markers is cen - D11S1354 - D11S4082 D11S1887 - D11S1780 - D11S1367 - TYR D11S931 - D11S1342 - D11S1358 - tel.

A test of hemizygosity was performed using this map as a framework. Results presented in table 1 show that D11S1367 was deleted in the patient, whereas D11S1887, D11S1780,

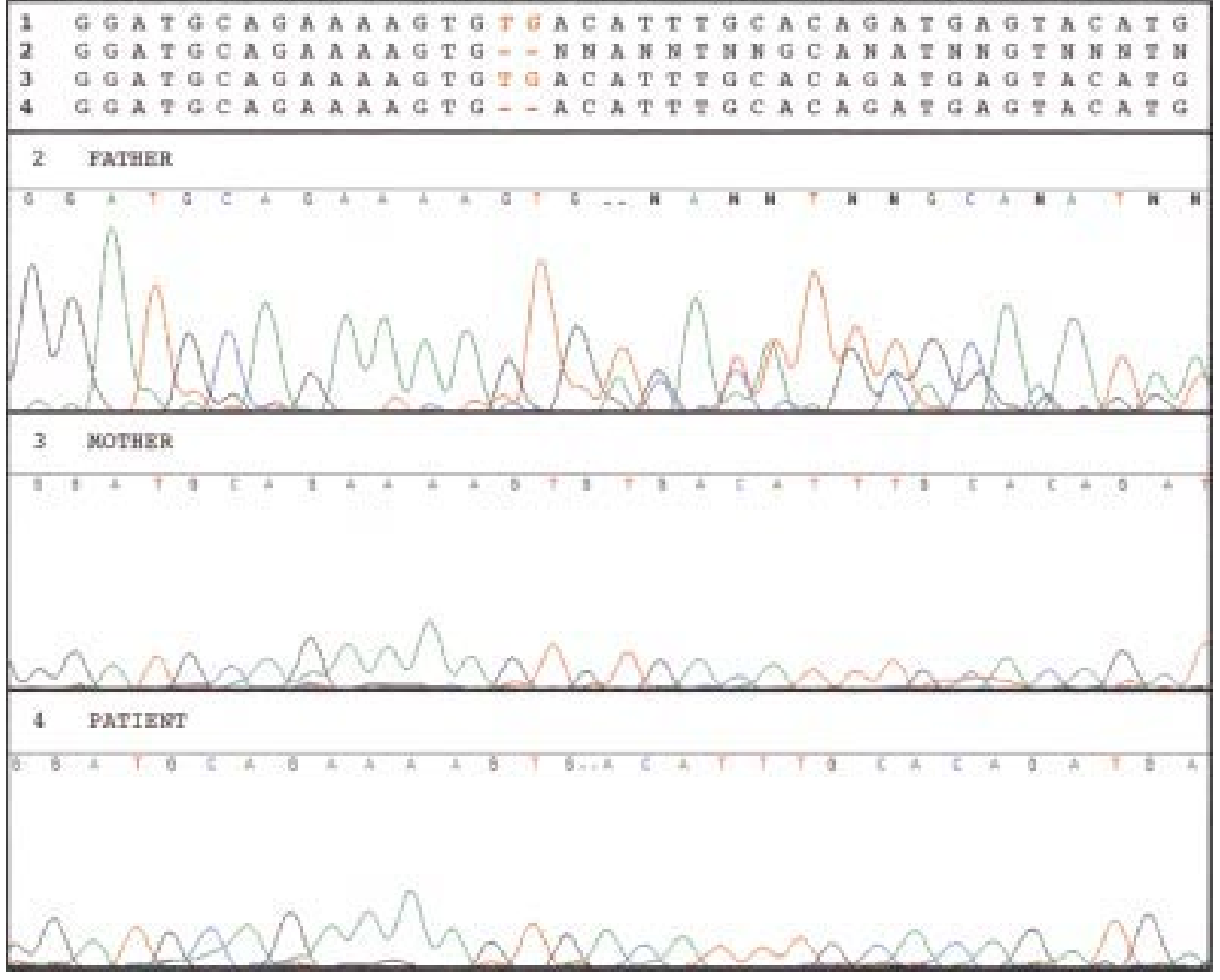

Figure 4 Sequence analysis of the TYR gene exon 1. Alignment of sequences for the patient (lane 4) and his parents (lane 2 father, lane 3 mother) compared to the TYR exon 1 reference sequence (lane 1) is shown. The sequencing reaction was performed using primer $P 1 B .^{2}$ The arrows indicate the deletion observed in the patient and his father. 


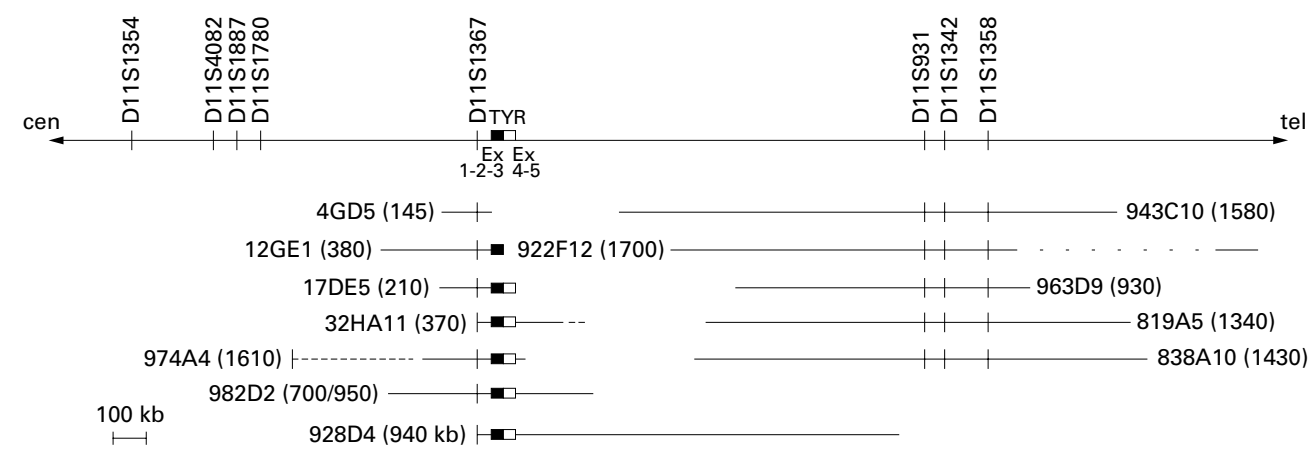

Figure 5 YAC contig map of the 11 q14.3 region. Markers tested are represented in the upper part of the figure. The presence of a marker in a YAC is indicated by a vertical bar. YAC sizes in kb are indicated in parentheses.

D11S931, D11S1342, and D11S1358 were not. The absence of a maternal allele at D11S1367 confirmed that the deletion had occurred on the maternal chromosome, as already indirectly indicated by the inheritance of the TYR exon 1 (TG) deletion at codon $244 / 245$ from the father.

In summary, our data indicate that the deletion found in the patient is framed by markers D11S1780 on the proximal side and by D11S931 on the distal side, a region estimated at about $0.6 \mathrm{cM}$ on the Marshfield map.

\section{Conclusion}

We describe a patient with a de novo $11 \mathrm{q} 14.3$ microdeletion presenting with both oculocutaneous albinism type 1 and leucodystrophy. The deletion was characterised at the molecular level both by FISH using a $T Y R$ probe containing the first exon of the gene and by showing hemizygosity at D11S1367. According to our physical mapping data, we estimate that TYR and D11S1367 are separated by about $100 \mathrm{~kb}$. The closest non-deleted markers found in the patient are D11S1780 and D11S931 (0.6 cM). Our data therefore suggest that a new gene responsible for leucodystrophy is present in $11 \mathrm{q} 14.3$. According to our contig mapping data (fig 5), the size of the deletion interval is larger than $1.4 \mathrm{Mb}$ (distance between D11S931 and the end of the 12GE1 YAC). The extent of the deletion needs further characterisation in order to search for candidate genes and identify the gene responsible for leucodystrophy in this patient. More than $40 \mathrm{EST}$ and genes are located in the critical region but their exact position on the map, especially their presence

Table 1 Test for hemizygosity using microsatellite markers from the 11q14 region

\begin{tabular}{lllll}
\hline \multirow{2}{*}{$\begin{array}{l}\text { Microsatellite } \\
\text { markers }\end{array}$} & \multicolumn{2}{l}{ Allele size $(b p)$} & \\
\cline { 2 - 4 } & Father & Mother & Patient & Comment* \\
\hline D11S1354 & $169 / 179$ & $179 / 179$ & $179 / 179$ & NI \\
D11S4082 & $123 / 127$ & $123 / 125$ & $123 / 123$ & NI \\
D11S1887 & $267 / 275$ & $261 / 261$ & $267 / 261$ & ND \\
D11S1780 & $183 / 191$ & $173 / 189$ & $191 / 189$ & ND \\
D11S1367 & $227 / 231$ & $227 / 233$ & $231 /-$ & D \\
D11S931 & $266 / 266$ & $261 / 266$ & $266 / 261$ & ND \\
D11S1342 & $261 / 265$ & $263 / 263$ & $261 / 263$ & ND \\
D11S1358 & $144 / 146$ & $137 / 144$ & $137 / 144$ & ND \\
\hline
\end{tabular}

Allele sizes are indicated in bp for each marker. ${ }^{\star} \mathrm{ND}$ : not deleted, NI: not informative, D: deleted. or absence in the deleted region, remains unknown. Attention will be particularly given to the genes and ESTs that are expressed in the brain, such as embryonic ectoderm development protein (EED), mitochondrial $\mathrm{NADP}(+)$ dependent malic enzyme 3 (ME3), and chapsyn-110 (DLG2). The cathepsin C gene, which encodes a lysosomal protease expressed in the brain, is another candidate, since most leucodystrophies of known cause are lysosomal diseases. ${ }^{3}$ Although the cathepsin C gene was recently identified as responsible for Papillon-Lefèvre syndrome, ${ }^{10}$ its potential role in the leucodystrophy of our patient will also be investigated.

The first two authors contributed equally to this work. We thank Fabienne Ballanger and Virginie Dupart for their technical contribution to this work. This work was supported by grants from Institut National de la Santé Et de la Recherche Médicale (CRI 9504), Association Française pour la Recherche en Génétique (AFRG), European Leukodystrophy Association (ELA), and Association pour la Recherche Médicale en Aquitaine (ARMA).

1 Kristjansdottir R, Uvebrant P, Hagberg B, Kyllerman M, Wiklund LM, Blennow G, Flodmark O, Gustavsson L, Ekholm S, Mansson JE. Disorders of the cerebral white matter in children. The spectrum of lesions. Neuropediatrics 1996;27:295-8.

2 Baraitser M. Metabolic disorders/degenerative diseases of childhood. In: The genetics of neurological disorders. 3rd ed. Oxford: Oxford Medical Publication, 1997:283-333.

3 Petit J, Boisseau P, Taine L, Gauthier B, Arveiler B. A YAC contig encompassing the 11q14.3 breakpoint of a translocation associated with schizophrenia, and including the tyrosinase gene. Mam Genome 1999;10:649-52.

4 Viégas-Péquignot E, Dutrillaux B. Une méthode simple pour obtenir des prophases et des prométaphases. Ann Genet 1978;25:122-4.

5 Giebel LB, Strunk KM, Spritz RA. Organization and nucleotide sequences of the human tyrosinase gene and a truncated tyrosinase-related segment. Genomics 1991;9: 435-45.

6 Cherif D, Julier C, Delattre O, Derré J, Lathrop GM, Berger R. Simultaneous localisation of cosmids and chromosome R-banding by fluorescence microscopy: application to regional mapping of human chromosome 11. Proc Natl Acad Sci USA 1990;87:6639-43.

7 Barton DE, Kwon BS, Francke U. Human tyrosinase gene, mapped to chromosome 11 (q14-q21), defines second region of homology with mouse chromosome 7. Genomics 1988;3:17-24.

8 Evans KL, Fantes J, Simpson C, Arveiler B, Muir W, Fletcher J, van Heyningen V, Steel KP, Brown SDM, St Clair D, Porteous DJ. Human olfactory marker protein maps close to tyrosinase and is a candidate gene for Usher syndrome type I. Hum Mol Genet 1992;2:115-18.

9 Oetting WS, Mentink MM, Summers CG, Lewis RA, White JG, King RA. Three different frameshift mutations of the tyrosinase gene in type 1A oculocutaneous albinism. Am $\mathcal{F}$ Hum Genet 1991;49:199-206.

10 Toomes C, James J, Wood AJ, Wu CL, McCormick D, Lench N, Hewitt C, Moynihan L, Roberts E, Woods CG, Markham A, Wong M, Widmer R, Ghaffar KA, Pemberton M, Hussein IR, Temtamy SA, Davies R, Read AP, Sloan P, Dixon MJ, Thakker NS. Loss-of-function mutations in the cathepsin C gene result in periodontal disease and palmoplantar keratosis. Nat Genet 1999;23:421-4. 